University of Minnesota Morris Digital Well

University of Minnesota Morris Digital Well

$1-3-2018$

\title{
The Ethical Benefits and Challenges of Biofiction for Children
}

Michael Lackey

University of Minnesota Morris, lacke010@morris.umn.edu

Follow this and additional works at: https://digitalcommons.morris.umn.edu/eng_facpubs

Part of the Children's and Young Adult Literature Commons

\section{Recommended Citation}

Lackey, Michael. 2018. "The Ethical Benefits and Challenges of Biofiction for Children." a/b: Auto/ Biography Studies 33.1:5-21.

This Article is brought to you for free and open access by the Faculty and Staff Scholarship at University of Minnesota Morris Digital Well. It has been accepted for inclusion in English Publications by an authorized administrator of University of Minnesota Morris Digital Well. For more information, please contact skulann@morris.umn.edu. 


\title{
The Ethical Benefits and Challenges of Biofiction for Children
}

\author{
Michael Lackey \\ This is an Accepted Manuscript of an article published by Taylor \& Francis in a/b: \\ Auto/Biography Studies on January 3, 2018, available online: \\ https://www.tandfonline.com/doi/full/10.1080/08989575.2018.1389820.
}

I don't think that biofiction for kids is very ethical. For most kids, it would be hard to tell if it is fiction or nonfiction. If they can't tell that it is fiction or nonfiction, they might have false ideas about what actually happened.-Anya Eckerle, age thirteen

In 2011, I started researching and writing about biofiction-literature that names its protagonist after an actual historical figure. My suspicion at that time was that these works would appeal to students, so by 2014, I had taught a number of biographical novels, including Arna Bontemps's Black Thunder, Zora Neale Hurston's Moses, Man of the Mountain, Joanna Scott's Arrogance, Julia Alvarez's In the Time of the Butterflies, Irvin Yalom's When Nietzsche Wept, Michael Cunningham's The Hours, and Lance Olsen's Nietzsche's Kisses. Student responses were so positive that in the spring of 2015 I taught a course titled "The American Biographical Novel," which was, by far, my most successful senior seminar. In this class, students spent considerable time examining the changes authors made to the biographical and historical record, and sought to explain the aesthetic justifications and values of such changes. But one student, who was an English and secondary education major, posed some very important questions: is this form of fiction suitable for children? In other words, given that authors of biofiction alter biographical and historical facts, should elementary or secondary education teachers use this type of literature in the classroom? If so, are there potential dangers? And how should teachers address these dangers?

As it happens, I have two daughters who were at that time nine and eleven. In an effort to understand better the value and potential danger of biofiction for children, I asked my daughters and a couple of their friends to read Jane Yolen and Robert J. Harris's biographical novel Girl in a Cage. During a dinner, we had an evening of conversation about the novel. The girls explained why they liked the novel and discussed some of the themes. But we also talked about some of the potential problems - that the authors invented some characters and scenes and changed some historical and biographical facts. It was during this part of the conversation that I discovered that there were deep divisions among young readers about the ethics of biofiction for children. For instance, my daughter Anya, who was twelve by the time of our conversation, voiced strong disapproval. To her mind, authors have an obligation to represent biographical and historical fact with as much precision and accuracy as possible, so strategic deviations from the truth are simply not acceptable because they could easily mislead readers. But my daughter Katya, who was ten by that time, said that readers should and would know that authors made changes because the work is clearly called fiction.

To my mind, both of my daughters made compelling cases in defense of their positions, so I decided to contact Yolen and Harris to see whether they would be willing to answer some questions about the nature, value, and ethics of biofiction for children. The interview took place 
on 20 June 2016 in St. Andrews, Scotland. The end result of the interview was not what I expected. Yolen and Harris did not try to argue that biofiction is valuable despite the strategic misrepresentations of the biographical and historical record. To the contrary, they suggested that biofiction is important for children and young adults precisely because authors take liberties with seemingly established facts.

Yolen and Harris make two changes that will surely give opponents of biofiction pause. In Queen's Own Fool, the character of Lord Darnley is killed, and Queen Mary's female jester, Jardinière, is a potential suspect. She flees and, to make her escape plausible, Yolen and Harris have the preacher John Knox conceal her in his home. The historical problem is that Knox was not even in the city at the time of the assassination. For those critical of biofiction, a more "egregious violation" can be found in Girl in a Cage. The main character is Marjorie, the daughter of the Scottish king, Robert the Bruce. The ruthless King of England, Edward Longshanks, wanted total political control, so he tried to kill Robert, and after capturing the eleven-year-old Marjorie, he imprisoned the young princess in an outdoor cage, where she was subjected to the jeers of the local population and the vicissitudes of the elements. As a symbol, Marjorie's experiences in a cage brilliantly picture the political tensions and battles between Scotland and England, but historically, they are most likely a total fabrication. We know that Longshanks imprisoned some older women, but as Harris says in the interview, he "would argue that" Marjorie "was never in a cage."

On what basis can Yolen and Harris make such obvious changes to the biographical and historical record? Key to understanding these writers' work is this aesthetic fact: as Yolen says, what they write "is not biography or history. It is using biography and history to tell a story." There are many reasons for taking liberties with the seemingly established facts. First, Harris notes that real history is messy and spread out, so aesthetic compressing is necessary for making a story "flow more smoothly." This compressing may lead authors to alter some biographical or historical facts, but this does not make the work "untrue to history." It just means that authors strategically package history in a particular way in order to maximize the effect on the reader.

Secondly, these writers use their biographical subjects as a way of illuminating a specific historical period. For instance, Harris has authored stories about Shakespeare and Leonardo da Vinci as teenagers, and while Harris acknowledges that the stories are totally invented, he also stipulates that "if children read those books, they would learn a lot about Renaissance Florence. They would learn a lot about Elizabethan England." This is the case because the "research is right, the world they are in is right, [and] the details of their lives are right." In this case, Harris uses da Vinci and Shakespeare not just to tell an entertaining story, but also to illuminate a specific time and place in history.

Thirdly, Yolen and Harris use their biographical subjects in order to communicate something that can apply to more than just their protagonist. Initially, the character of Marjorie is a superficial little girl who thinks only about herself and the materialistic benefits of being a princess. But after being imprisoned in a cage and witnessing how everyday people live, she undergoes a transformation. Through this character, readers see, as Yolen says, "a girl who could have been like any rich, spoiled girl." To put the matter simply, there is something in Marjorie's story in the fourteenth century that could apply to someone in our own time. 
The most fascinating part of the interview was the writers' extended reflections on the pedagogical value of getting history "wrong" in biofiction. In her closing remarks, Yolen encourages young readers of biofiction to determine whether "there is something in the novel that is historically inaccurate or not in the historical record. If so, then one needs to clarify why that is in the novel." What informs this comment is the view that history is fiction. Authors of biofiction have a particular objective, so they strategically select and organize biographical facts and historical information in order to communicate their vision. Harris makes this point succinctly: "What we are doing is texturing those stories, taking different bits and joining them together to make something that is really meaningful." But this is not something that only fiction writers do. As Yolen says, "the word history has the word story at the end." Thus, "if historians tell you that they have never tampered with or made a judgment that combines two facts and tries to find a way to fit them into a coherent narrative, they are out of their minds." Harris makes a similar observation about journalists: "In newspapers, you get a viewpoint. They are not just telling you the fact. They are giving you their angle on a story." All writing is told from a particular perspective and is based on an arbitrary selection of facts, but there is one major difference between history and fiction. Fiction writers acknowledge that their work is fiction, while historians suggest that their work is not fiction by calling it history.

What makes biofiction so valuable for children, then, is that the writers invite and even demand that their readers ask: why did these writers select and organize the information as they did? Why did they make specific changes to the biographical and historical record? What were they trying to achieve through these strategic alterations? There are two separate ways of answering these questions. The first is narratively specific. Both Yolen and Harris acknowledge that the image of a girl in a cage has considerable power as a metaphor. Therefore, this image could be used to describe not just Marjorie's personal situation, but also what other people experience. So, in the novel, the Countess of Buchan describes her situation as a young woman, and she vows that "no one will cage me that way again" (57). In a conversation with Longshanks, Marjorie realizes how the king is in thrall to his lust for power, which is why she concludes that he "is as much caged as I" (133). Near the end of the novel, Marjorie begins to realize that even the soldiers who guard her are psychologically imprisoned: "From the cage I can see eight soldiers in their green surcoats and shiny helmets. They are stationed at various points, each an equal distance from my cage. It is as if invisible lines run from guard to guard, and these lines form the outer wall of my prison. Invisible bars around an invisible cage" (209). Put simply, Yolen and Harris use the cage image to underscore how so many people are politically, intellectually, and psychologically imprisoned, and thus they offer ways of escaping from their physical as well as their metaphorical cage.

The second way of answering the questions is more fundamental. Yolen and Harris want to inspire their readers to become more curious, critical, and active readers of biography and history. What readers get in biographical novels is not objective truth. Rather, the authors openly admit that they have made strategic changes to the biographical and historical record in order to achieve their aesthetic objectives. Therefore, readers should not passively accept their works as unvarnished truth. Indeed, they should read more history to see whether the writers' vision makes sense. And if not, then the readers should form their own vision.

Since both writers consider history and journalism to be a form of fiction, they believe that readers should approach history and journalism in the same way they approach fiction. In 
essence, the authors" overt and strategic "liberties" with the historical record present in biofiction are precisely what make this genre so valuable for teachers of children and young adults. Taught correctly, teachers of biofiction will give students more than just engaging and important stories about critical figures and events from the past. They will help students develop a critical faculty for engaging biography, journalism, history, and fiction, and, in the ideal case, inspire students to do their own research and subsequently to formulate their own vision not of history, but of the story of the past.

\title{
An Interview with Jane Yolen and Robert J. Harris
}

\author{
Interviewed by Michael Lackey and Katya Lackey
}

Michael: Let me begin by telling you about the nature of this project. Biofiction-literature that names its protagonist after an actual historical figure-has become a dominant literary form. In recent years, scholars have been trying to define the nature of this aesthetic form and to explain why it has become so popular with academics as well as the general population. With regard to your work, and here I am thinking about your biographical novels Girl in a Cage and Queen's Own Fool: A Novel of Mary Queen of Scots, there are concerns because some of what you say is made up and you sometimes change historical facts. This obviously raises ethical questions, especially for young readers, who are your target audience. My scholarly objective is to address both the values and the potential dangers of biofiction for children and young adults.

Jane: Can I say, before we start, you have to remember that we wrote these books more than ten years ago, and we did the research for them earlier than that. We are discussing what we did long ago, so what I say today is what I think I remember. And to complicate matters more, Bob will probably have a different idea of what we discussed when we were working on these novels.

Robert: In other words, you can expect some friction here or some interrupting. At some point, one of us is likely to say, "No. That is not what happened."

Michael: That is very useful, and I suspect that your challenges in remembering the process of composing the novels will mirror the challenges we face in accessing and representing the biographical or historical past. My daughter, Katya, has a question that might bring some of these challenges to the surface.

Katya: In Queen's Own Fool, why did you tell the story from the fool's perspective instead of the queen's, when the novel is about Mary Queen of Scots?

Robert: It was in Stirling Castle that we got the idea.

Jane: That's right. I had been to Stirling Castle a number of times, but on this particular occasion, I saw a little plaque that said, very boldly, "Mary, Queen of Scots had three female jesters or female fools." One or the other. I can't remember. I found that fascinating, which made me wonder, "Who knew there were women jesters?"

Robert: And when you discover that these girl jesters were in the court, that is an interesting idea for a character, but it can also be useful for the perspective that you give the character. 
Jane: Knowing something about these jesters is interesting in itself, but for my part, telling the story of Queen Mary from the fool's perspective gives us a larger perspective, because the queen didn't know herself very well. She was caught up in two histories - the French and then the Scottish. Had we narrated the story strictly from the queen's point of view, that would have been a different kind of story. This was a young adult book, so we wanted the view of a younger person, someone who could offer an alternative perspective from the queen. With regard to our narrator, not only is she younger but also from a different culture and status. She is a young Italian street performer who has been elevated in status by becoming part of the queen's train. That gives her a different perspective and a way to interact with the underlings that the queen wouldn't have had. You have to remember, with royalty, people serve in order to elevate themselves. So, the queen frequently gets biased information, and she is trying to sort through it: "What of this can I believe? What of this should I not believe?" The narrator sees all this from a different perspective.

Michael: So, this narrator is totally fictional?

Jane: We don't know the actual names of the jesters, but we know their nicknames. When we looked them up in the castle records, one was called "Jardinière."

Robert: We picked that one and made it her.

Jane: There was one that was just called "La Folle," and so we made her the traditional jester, which would have been some kind of dwarf. At that time, the upper classes loved to laugh at people with disabilities, because they were not considered quite human. Another one was a tutor, our girl's tutor in the ways of the court. That is all we discovered. The only other thing we found out about these three was that they went to Scotland. We know that because, in the castle rolls, before the queen goes to England, she gave them some money, some gloves, and I think a jewel or something like that. That is all we know about them. Given that there was so little information, we were able to use them as interesting characters, because we had to reinvent them.

Robert: Also, because we have got a character we don't know anything about, especially her point of view, we gave her a personality. If you are writing a novel from the point of view of Queen Mary, you actually have to take in everything about her. You have to try and represent what she would have been like. Of course, the difference with Mary is that she is the queen with all this power and authority, and can send people to get beheaded, whereas a little girl in her court has no power at all, and the great danger in a story, which I tried to avoid, is that she would just watch things happening, because the plot basically follows scenes of historical events which actually happened.

Jane: There is one thing we made up. After Darnley is blown up, people are searching for who was involved, and our girl is running through the streets of Edinburgh, and she is taken in by John Knox. Actually, and we say this in a prefatory note, John Knox was not in the city at that time. He was off preaching somewhere, but we needed some way of getting her off the street while the search was going on.

Robert: Also because he is a very unsympathetic character in the book. 
Jane: And we wanted to make him a little more sympathetic.

Robert: We wanted to show another side of his character. He wasn't just preaching against the queen. He was also a man of moral courage. We wanted to avoid having a cartoon character. So, this scene was written first, and it was only afterwards that we discovered that he wasn't even in Edinburgh at the time. Given this conflict with the historical fact, what were we to do? Should we abandon the scene? It is a really good scene dramatically for the story and the character. It tells you an awful lot about these characters. But you have to keep in mind that a biographical or historical novel is not the same as a history book.

Michael: Can I follow up with a question on all this? Both of you know Susan Sellers, who has written the biographical novel Vanessa and Virginia, which is about Vanessa Bell and Virginia Woolf. Susan said that she did extensive research for that novel, but once she understood the nature and logic of her characters and story, she put the established facts aside. Her loyalty from that point forward was to the logic of her characters and story rather than the facts about Bell and Woolf. Would you say that you two did the same thing with your novels? And you don't have to restrict your answer just to Queen's Own Fool. You can talk about Girl in a Cage as well.

Jane: With regard to Girl in a Cage, we know practically nothing about the girl or what happened to her in the two weeks that she was in a cage. We know that the king was pressured into letting her go. He had a sort of mini rebellion on his hands, and so he put her into a nunnery.

Robert: I would argue that she was never in a cage, but some women were put in cages and he was going to put her in a cage.

Jane: We made a leap that she was like the other women who actually were put in a cage- - her two aunts and the Countess of Buchan. The two aunts were eventually freed after the war, but I think they spent the whole war in the cage.

Robert: But this image of a girl in a cage - there is a powerful idea that a girl this young, a child, is put in a cage by an evil king who is dying of cancer at the time. He is evil from our point of view. In his head, he is trying to conquer a country. It is such a great idea because it tells you a lot about the period. It is a great way to tell the story of this time and these characters, but it also has a great resonance for today as well.

Jane: But this image of a child in a cage poses a problem: you have a girl in a cage for two weeks and how do you do that? At least with the Mary story, they are moving here and they are moving there while great forces are happening. Once Marjorie is put in a cage, you have got most of a novel where she is in a restricted space. The problem is not how much we knew or didn't know or how much we were attending to the actuality. Once we chose her as the main character, we are not seeing the rest of what is going on. If you choose the king or the queen, you are seeing a larger chessboard. If you choose the girl in the cage, you are seeing the square, and that is the difference.

Michael: So, what you say about this biographical figure is not actually true. But can you specify the kind of truth you are giving to readers through this girl? 
Jane: But we don't know if it is really true or not true. That's the thing. We don't know and neither do you.

Michael: And I get that. But what I am asking you is this: you are giving us certain kinds of truths through this character, and I am trying to see if you can specify the nature of the truth. Now, Bob, you said something really interesting. You said, "Look, it is in part about what is going on in this time period. I am giving you a historical view." But you also said it has some relevance today. Can you talk a little more about the dual temporal nature of this truth?

Jane: I think you are seeing a girl who could have been like any rich, spoiled girl. We see how she acts under pressure, how she acts to the people outside her, maybe at the beginning because she needs something from them. She needs food. She needs somebody to send messages. That sort of thing. But she becomes genuinely fond of the people and, through this, she grows enormously from the spoiled princess who just wants superficial things like dresses and jewelry to a very strong woman.

Robert: Let me provide some background information. The idea of a girl in a cage is a very powerful notion. But is this going to be a linear story? On the first page, you see her in a cage. But then you go back and tell the whole story up until then and what happens after. It seemed that the best way to narrate the story was through a series of dialogues between her and the king. So, the backstory about Robert the Bruce's rebellion is in chapters in between, in flashbacks. We wanted the tension of the girl in the cage to be present for the whole book, and the climax would be her actually being released. The first complication is that you have to interweave the chapters so that they reflect each other. You have the present-day chapters in the cage, but then you also have what happened in the past that led to her situation, and it is important that the ideas connect up nicely. You don't give away something in one bit that is going to be revealed later. That was actually really hard and complicated work.

Jane: As I remember it, we had a lot of arguments, too, trying to figure out how to do it.

Robert: It was hard work getting that structure. To me, the novel is not just about her as a character, but about her effect on other people. There is some debate about Robert the Bruce's character. People contend, "So he was just some nasty, greedy warlord rather than some heroic figure." But in history there were so many people who were prepared to die for him. As a person, he actually was a brave warrior, a heroic guy. He had this charisma. People made him king and he was a great king.

Jane: But he was also flawed, and he acknowledged his flaws and he grieved over them. And that, to me, is very admirable. I like humility in my heroes.

Robert: Important to me in the book is that the country comes behind him because he brings people with him. When the English army is coming and he has to flee, he is out there fighting guerilla war, taking the country back castle by castle with this tremendous determination and courage. Marjorie's experience in the cage parallels what happens to her father. At first, the local children of Lanercost (the town in England where Marjorie is a prisoner) start by mocking and throwing things at her. But bit by bit, as Marjorie grows as a character, they start growing too. And they start coming together around her. 
Jane: They come into her aura.

Robert: These children become like a court, so the monks start to get involved. Eventually, in the climax of the book, all the people in the area rise up at once, and Edward has the choice of either letting her go or killing everybody. So, it is like a rebellion has begun here in the same way. The courage of one person has brought everybody together. And that is like real heroes. Real important people in history make everybody else rise up and become better.

Jane: These heroes don't just run ahead shouting, "Me! Me for Scotland!" and "Where the hell are my followers?" They have gathered them together, and that is what she does from the cage.

Robert: So, it is making a parallel story of what her father has done and what Marjorie has done on a smaller scale from her cage to make people rise up. Let me give you a contemporary example to illustrate. It is like the years when our children were young and the communists wanted to take over Russia again. The government put Gorbachev under house arrest and they put tanks in the street. Boris Yeltsin was standing on a tank getting the people to rise up, and eventually these old men who were trying to set the clock back said, "Right. You have to go out there and just shoot people down." And the generals in charge of the troops said, "No. We are not going to do that." And these old guys just went away. It is kind of like that. People rise up, and there is a point when somebody just says, "No, we are not going to do this." That to me is great, and it is really a strong parallel.

Jane: I think what Bob is also getting at is when you are writing a book that has historical parts to it, yes, you are trying to be true to that particular history, but we also know a lot of other history. And if that other history intrudes in some way, it just makes things stronger and better. And obviously, if you are writing it strictly from the point of view of somebody in the thirteenth, fourteenth, fifteenth century, they are not going to know what happened one hundred, two hundred, three hundred years later-but we do. And we are hoping our readers do, too. And maybe they don't know a lot of it, but maybe it will excite them to go and learn more. That is what I think a biographical or historical novel does.

Katya: When you chose Marjorie to be your main character, you would have known she would be in a cage for a lot of the story. But did you think about choosing another character to be the narrator, one that wouldn't be in a cage? Why did you choose Marjorie to be the narrator?

Jane: Again, it has to do with who is seeing what and how do you want to tell the story. Yes, we could have chosen one of the children in the village, but they wouldn't have known any of the backstory. They wouldn't have known Robert the Bruce. They wouldn't have ever met him, and he is very much a part of the story. They wouldn't have known her Uncle Neil, who is killed and why he is important. So you have to decide when you are telling a story, when you are choosing the character you are going to have as your eyes and ears, you have to decide what part of this story you want to tell, how much of this story needs to be known to the character, and what does choosing that character do to the rest of the story that you are trying to tell. Obviously, if your character is going to die halfway through the novel, then you are going to be writing a fantasy of them looking down from heaven. That is a totally different kind of tale, isn't it? In Queen's Own Fool, we could have had La Folle tell the story, but she was not a very verbal character and not one who gave much thought to things. She was a reactor, not an actor. And we couldn't tell it 
from the young prince's point of view, the young French prince who became king, because he dies before Mary gets to Scotland. We needed someone who could be at the places we needed the character to be along with Mary, because that character becomes the camera watching the whole story. Once you choose that camera, you have several problems. Can they be at all the special times? If they are present at every major event, this gets a little hokey. I call that the "behind the arras" school of writing biographical or historical fiction.

Robert: You want to avoid that. You don't want a character saying, "As I hid behind whatever, I overheard these characters say this ...." That approach makes the character just an observer.

Jane: Over and over and over again.

Robert: For us, it is important that our character has her own kind of story. For instance, in Queen's Own Fool, when Darnley and the conspirators make Mary a prisoner, they are basically having an insurrection. In the real history, Darnley changes his mind and he frees Mary and they escape together and raise an army to stop the conspirators. That is a nice little chink there because what we suppose is actually that our girl jester climbs up into the window and starts telling him things that make him suspect that these guys will kill him off as well. And that is how she gets to have a very pivotal role.

Jane: We really don't know why he changed his mind, but he did in the historical record, which seems out of character, so we had to invent a way to account for that within our novel. We made him not very smart — which he wasn't — and had Jardinière manipulate him. The girl manipulates him into helping Mary escape, and we know that he actually did help the queen escape.

Robert: This enabled us to give our character a real influence on things, but also to make things happen the way they did. This addition makes perfectly good sense within the context of history and our novel. There were these real girl jesters, but our version is a fictional character. As writers, you notice these gaps in history, which we filled in: "She could have been there and she could have done that." So she gets to play a role in this event. Here you have a character who cannot draw a sword and fight people and has no authority, but she can do this and be clever.

Jane: Biographical and historical novelists love these gaps in history because that is where we can tell our stories. The further back you go, the more gaps you have. For instance, we know Queen Mary gave presents to these three women, but we don't know anything about the women. That implies that they meant something to her. They were important to her. They were just underlings. They were just servants, but these were the servants that she gave gifts to. Why did she give gifts to them? That is interesting, isn't it?

Robert: Just a small note on historical things, as when we have the description of Bruce's coronation in the flashbacks of Marjorie's story. In real life, the events took place over three days, but as a writer, you want to avoid saying, "On the next day this happened ...." No, you put it all on one day because that makes the story flow better. Real history is messier and takes longer. Compressing it is not untrue to history. It just makes things flow more smoothly. Who cares if the Countess of Buchan showed up two days later? Just have her show up on the day of the crowning. That way you get the drama of the thing. 
Michael: I have noticed that many historians are extremely critical of historical and biographical novels. Their argument is that these works distort the facts. But I have noticed that many novelists are not just interested in a truth of one time. They are trying to get to a truth that can also apply to other times and places. For instance, in Girl in a Cage, you have Isabel tell Marjorie how she was in a cage when she was young. In this instance, she is using the cage metaphor in a very different way. She says, "No one will cage me that way again." This resonates, because you have established this powerful metaphor that applies to people who are not in a physical cage. Now, I would never critique a historian for failing to convert a historical event into a metaphor or symbol, but historians feel comfortable critiquing creative writers for altering facts in order to create a metaphor or symbol that can be used to make sense of something from the past and the present. Can you talk about the metaphorical or symbolic significance of your work?

Jane: We are telling a story in the best way we can. We are telling it the way it feels right to us. We are trying to be as true to the historical record as possible, but understanding also that there are conflicting views, especially when you are looking at someone like Queen Mary, where you have the Protestants and the Catholics arguing for centuries and writing their own view of who she was. And there is no way to parse it entirely. All of these women have been manipulated and have done their manipulations all the way through this whole story. Trying to tease out actually why they did is challenging because someone is writing the historical record and telling you why they did it. That is as much fiction as what we are doing - only we are calling it fiction and they are calling it history.

Robert: I don't know all the technical differentiations, but there is quite a difference between different kinds of historical novel. I mean, Queen's Own Fool follows the historical events very, very closely. But we sometimes tweak history, as we did with John Knox, but you don't suddenly have someone who was murdered survive. You follow the actual events all the way through. In Girl in a Cage, the cage thing is kind of fictional, but the background of Robert the Bruce's rebellion that is told as a backstory is all true. In both books, you are getting a lot of history.

Jane: What I am really trying to say over and over again is that the word history has the word story at the end. And if historians tell you that they have never tampered with or made a judgment that combines two facts and tries to find a way to fit them into a coherent narrative, they are out of their minds.

Robert: Let me make a distinction between historical novels and actual history. I have written a couple of historical adventures, one about Leonardo da Vinci and one about William

Shakespeare as teenagers. They are historical adventures. They are not historical novels based on historical events. They take a few weeks or months out of their characters' lives and give them a completely made-up adventure, but against a genuine historical background. The research is right, the world they are in is right, the details of their lives are right, but they are having an adventure that there is no evidence ever really happened. They have sword fights and daring escapes. That is a different kind of historical writing, and if children read those books, they would learn a lot about Renaissance Florence. They would learn a lot about Elizabethan England.

Jane: But since these are books for children or young adults or middle grade, we are hoping that a child or a young adult will read them and then ask, "All right, what is true about this?" We 
always put a "What is true about this?" in the back of our books. But then they will go further and they will say, "Okay. Here is where they deviated from the facts in telling the story." So it is a teaching tool for exploring that period.

Michael: This raises a really important question among scholars, because we make a strict distinction between the historical novel and the biographical novel. This distinction was first made in 1937 by Georg Lukács. Lukács said, in the historical novel, you have actual historical figures that are on the periphery, but the central figure is an invented character that functions as a sociohistorical symbol.

Jane: And it is also your camera. It is your camera eye.

Michael: That's right. And so what you do in the historical novel is to examine the way circumstances in the environment shape and determine a consciousness of the invented figure. The biographical novel, which Lukács condemned, features an actual historical person, and he said that this was a huge mistake. But the biographical novel has become a dominant aesthetic form in recent years. One could even say that it has supplanted the historical novel.

Jane: This is because we want stories with heroes - that is, the celebrity, and we are just wild about celebrities. We are not as interested in the butler's take on Prince William as we are in Prince William.

Robert: So, is this guy saying you must not write biographical novels?

Michael: He thinks that there is something intrinsically wrong with the biographical novel. He thinks that if you center the novel within consciousness of an actual historical figure, you are, of necessity, going to give people a distorted perspective of history.

Jane: I want to say that I think it is a huge mistake for anybody to tell creative people that it is a mistake to do this or that. Because without doing that, we have not explored to the largest extent what we creatively can do.

Robert: I think it is actually a bit patronizing towards readers to say that they are not intelligent enough to understand that a novel, even if it is a biographical or historical novel, is a work of fiction. In newspapers, you get a viewpoint. They are not just telling you the facts. They are giving you their angle on a story. They have got their own political viewpoint. Everything you read comes with a viewpoint. So, if you are reading a novel about Shakespeare, you know that it is just this guy's view of him.

Michael: But can you explain, at least from your perspective, why there has been this shift from having an invented figure at the center of a novel to an actual historical figure? Why did you two do that?

Robert: I was unaware of any such shift, of any trends going on. Jane came to me and said, "I've got this idea for a novel, and we should write it together." And I just did it. 
Jane: These may be useful and important distinctions for critics and historians, but they are of absolutely no interest to the people who are writing books.

Robert: We just think there is a good story to tell. You don't say to yourself, "Here is a historical snippet that possibly Robert the Bruce's daughter Marjorie was put in a cage." You first think, "What a powerful idea." And even before the cover is painted, you can see it in your head.

Michael: Russell Banks said something similar in my interview with him. He wrote this wonderful biographical novel called Cloudsplitter, which is about Owen Brown, the son of John Brown. I asked him, "Have you given readers an accurate picture of Owen Brown?" He said, "No." He then went on to say, "I found something really important in this person's story, so I used it to make a larger point." Would you say you two are doing something similar?

Robert: I would say that in historical and biographical fiction, in a very general sense, history is the material for the story, but it is not the story. As a writer, you are obviously picking and choosing what you emphasize, and you also gloss over certain things. For instance, in my novel Will Shakespeare and the Pirate's Fire, Shakespeare stays at the house of John Dee, the astrologer to the queen. Dee had a wife and kids, but if there is nothing for them to do in the book, then you don't include them. These people clutter up the book, so there is no mention of them. As an author, you are focusing on who the story is about, so you are picking and choosing. This is an adventure story with spies and pirates and sword fights and things.

Jane: But it is also about Shakespeare as a boy, and we don't know anything about him as a boy.

Robert: We have no idea if he met John Dee or he met Walter Raleigh at ten when Raleigh was twenty-one. In the novel, all the people are real, but you are using Shakespeare as a character arc to bring them together into this story, which is a swashbuckling adventure full of intrigue. So this is historical. It is like you are saying, "Here are real characters who all meet up in this one story." The whole background of the Elizabethan world is real, theaters and all that. You are taking characters who are genuinely very colorful and just using them as material for fun. It's the same with the film Braveheart. This is a great film. But historically, it is just nonsense. Everyone understands that in a movie you just play around with the facts. Movies can be great even if they don't really follow history. People want to be entertained. If you make an accurate film that factually uses all the history, the viewers would fall asleep watching it. Biographical and historical fiction can be the same. It is painstakingly detailed, but nobody wants to read it because it is just a complete bore. Good fiction takes something from history and says, "Let's just do this with it." Stories come out of your imagination and you write them and you find material in history that inspires you and excites you and you want to use it.

Jane: That is what I was saying earlier; we love the holes in history because that is where you can add something. But never forget that it is a novel. I think Bob and I have said this over and over. Never forget that this is fiction. It is not biography or history. It is using biography and history to tell a story. And if we are good at what we do, if we are persuasive with what we do, we can make a point about biography and history, which we may not even realize we are making. But it is not actual. This is still a novel. 
Robert: So, in doing biographical fiction, you are doing somebody else's life. The story is not totally untrue. What we are doing is texturing those stories, taking different bits and joining them together to make something that is really meaningful.

Jane: And that is what a storyteller does.

Robert: I don't know if I can draw a scholarly point from all this. As authors, we are committed to storytelling and being true, taking true things and telling people a story that is meaningful and has got a lot to it. But you have to work the story. You can't just say, "This happens, this happens, this happens." Otherwise you have lost it all. You have lost the audience, and you wouldn't have anything left.

Jane: From a scholarly perspective, let me suggest three questions for readers of biofiction. First, one needs to ask if it is a wonderful book. Second, one needs to determine if the work communicates a truth. Third, after reviewing the book, one needs to figure out if there is something in the novel that is historically inaccurate or not in the historical record. If so, then one needs to clarify why that is in the novel. To get an answer to this last question, one should ask the author. But if the author is not around, then the reader must make an educated guess. And to my mind, that is what a teacher does in the classroom. Teachers should not just say, "They should be doing this, they should be doing that." Rather, they should be asking, "Did the author succeed? Did he or she pull it off?"

Robert: I just turned in to my editor a historical adventure novel set in Victorian Edinburgh. My wife edited it, but I also sent it to a friend who knows a lot about history. When I sent her the whole manuscript, I said, "Read this and tell me anything that isn't right or things I should put into this." I said in the introduction I sent her, "Here are all the things that I know that aren't historically accurate and here is why." For instance, there are these kids from a boarding school. They are Scottish kids from Edinburgh, but they are at a Jesuit boarding school in England, and they would not have been home for Christmas. But for my story, they have to be home because the story is taking place in winter. So, I have glossed it a little in order to make the story. As an author, your objective is to make a story. My friend pointed out things, saying, "I am fine if you do this or not because you are making an informed decision. You are not getting things wrong because you are ignorant. You are making artistic decisions about what will work for the story." I do a lot of visits to schools, and one of the things I do there is tell stories from my own childhood, in which I place connections and reflections I would not have thought of at the time but which are true nonetheless. If I can do that with my own life, I feel I can do it with the life of a historical character also.

\section{Acknowledgements}

I would like to thank the University of Minnesota, Morris for supporting this project with funding for travel to Scotland to interview the authors and for my research assistant. I would like to thank my research assistant, Zoe Blumhardt, for her excellent work transcribing the interview and for compiling a bibliography of biofiction for children and young adults. Above all, I would like to thank Jane and Bob for doing the interview. For a bibliography of young adult biofiction, compiled by Zoe Blumhardt, please see supplemental material. 


\section{Works Cited}

Yolen, Jane, and Robert J. Harris. Girl in a Cage. New York: Speak, 2002. Print.

—. Queen's Own Fool: A Novel of Mary Queen of Scots. New York: Speak, 2000. Print. 